\title{
DEVELOPMENT OF SUCCESSIVE CAMBIA AND WOOD STRUCTURE IN STEM OF RIVEA HYPOCRITERIFORMIS (CONVOLVULACEAE)
}

\author{
KISHORE S. RAJPUT
}

\begin{abstract}
This study examined the formation of successive rings of cambia in Rivea hypocriteriformis Choisy (Convolvulaceae). The mature stem is composed of four to five rings of xylem alternating with phloem. Successive cambia originate as smaller and larger segments; union and anastomosing of small cambial segments often leads to the formation of discontinuous rings. In the initial stage of growth, several vascular bundles interconnect to form the first ring of vascular cambium. The cambium remains functional for one complete season and becomes dormant during summer; a new ring of cambium is completed prior to the subsequent monsoon season and sprouting of new leaves. Successive cambia are initiated from the pericyclic parenchyma situated three to four cell layers outside of the protophloem. Functionally, all the successive cambia are bidirectional and produce secondary xylem centripetally and phloem centrifugally. The secondary xylem is diffuse-porous, with indistinct growth rings and consisting of wide fibriform vessels, fibre tracheids, and axial and ray parenchyma cells. The xylem rays are uni- to multiseriate and heterocellular. The multiseriate rays contain lignified marginal ray cells and thin-walled, unlignified central cells. The central ray cells also show accumulations of starch and druses. Discrete strands of intraxylary phloem occur at the periphery of the pith, and additional intraxylary phloem develops from adjacent cells as secondary growth progresses. Earlier-formed phloem shows heavy accumulation of callose, followed by its compaction. The development of successive cambia is correlated with extension growth and with the phenology of the plant.
\end{abstract}

Key words: anatomy, cambial variant, fibriform vessels, intraxylary phloem

Kishore S. Rajput, Department of Botany, Faculty of Science, The Maharaja Sayajirao University of Baroda, Vadodara 390 002,India; e-mail: ks.rajput15@yahoo.com

\section{INTRODUCTION}

Successive cambia occur in various members of the Convolvulaceae. This was known more than a century ago (Hallier 1893) and has been reported a number of times since then (Pfeiffer 1926; Metcalfe \& Chalk 1950; Obaton 1960; Pant \& Bhatnagar 1975; Lowell \& Lucansky 1986; Carlquist \& Hanson 1991; McDonald 1992). Most of these cited studies are based on dry wood samples of the Convolvulaceae; as a result, xylem anatomy is thoroughly studied while the development of the cambial variant is neglected, since soft parenchymatous cells and meristem tissue are poorly preserved in dry samples. Previous studies of fresh samples by me and co-workers (Rajput et al. 2008, 2013, 2014) revealed several interesting facts not reported in other work. Our research on Ipomoea demonstrated the presence of successive cambia in which every alternate cambium is functionally inverse; that is, xylem is produced externally and phloem internally. In two species of Argyreia Lour., Pant and Bhatnagar (1975) described the development of medullary bundles. Carlquist (1991) studied 35 species of the family, some of which lack successive cambia. In light of those findings, it was expected that, like other genera of the family, Rivea Choisy might exhibit unique features. Perusal of the literature indicated that little information is available on the secondary xylem structure of Rivea (Metacalfe \& Chalk 1950), and that information on the development of the cambial variant and on structural details of its derivatives is lacking.

Rivea hypocrateriformis Choisy is a perennial woody climber and thrives well in dry habitats. 
New leaves sprout prior to rainfall, and flowers appear in August-September, followed by fruit set and maturation in subsequent months. Maturation and yellowing of leaves starts in November-December and the plant becomes completely leafless in January. Initiation of cambial activity and differentiation of secondary xylem and phloem is correlated with phenological events in timber trees (Evert 2006). The main aims of the present research were to elucidate the structure and development of the cambial variant and the structure of secondary xylem and phloem, and to determine any correlation between cambial activity or initiation of successive cambia in $R$. hypocrateriformis and sprouting of new leaves.

\section{Materials AND MEthodS}

Five or six segments of $30-45 \mathrm{~mm}$ long pieces were collected from main stems of Rivea hypocrateriformis plants 6-7 $\mathrm{m}$ tall, starting from the shoot apex up to the $15^{\text {th }}$ internode and thereafter at $30 \mathrm{~cm}$ intervals to ground level. Thick stems $c a 50 \mathrm{~mm}$ in diameter were also collected from main stems and immediately fixed in FAA (Berlyn \& Miksche 1976). To determine the number of successive cambia initiating in one growing season, some newly initiated shoots on mature plants were tagged in May 2008 and collected at two-month intervals up to June 2009. Trimmed pieces of young shoots were processed for paraffin embedding by the routine method described by Berlyn and Miksche (1976). Samples were dehydrated through a tertiary butyl alcohol (TBA) series, infiltrated with paraffin and embedded in it. Paraffin-embedded blocks were sectioned with a Leica RM 2035 rotary microtome, and thick woody samples were sectioned directly with a Leica SM2010R sliding microtome. Transverse, radial and tangential longitudinal sections $15-20 \mu \mathrm{m}$ thick were stained with safranin-fast green (Johansen, 1940). After dehydration through an ethanol xylene series they were mounted in DPX.

For measurement of the length and width of vessel elements, fibriform vessel elements and xylem fibres, small pieces of xylem adjacent to the outermost cambial ring were macerated with Jeffrey's fluid (Berlyn \& Miksche 1976) at $55-60^{\circ} \mathrm{C}$ for 24 to $36 \mathrm{~h}$. Macerated pieces were stained with $1 \%$ aqueous solution of safranin, and temporary slides were mounted in glycerine. The length of fusiform cambial cells and sieve tube elements was measured directly from tangential longitudinal sections.
Thirty random measurements were used to calculate means and standard deviations. Wood descriptions follow Wheeler et al. (1989) and Carlquist (2001).

\section{RESULTS}

STRUCTURE OF YOUNG STEM AND DEVELOPMENT OF SUCCESSIVE CAMBIA

In young stems, a compactly arranged single-layered epidermis covered with cuticle encloses the hypodermis. The wide cortex is composed of compactly arranged, polygonal, thin-walled parenchyma cells; the endodermis and pericycle are indistinct (Fig. 1A). On the inner side of the pericycle, several conjoint, collateral and open vascular bundles joined by interfascicular cambium form a complete cylinder of vascular cambium. Fusiform cambial cell length ranges from 382 to $387 \mu \mathrm{m}$. The cambial rays are uni- to multiseriate, ranging from 256 to $464 \mu \mathrm{m}$ in height and 22 to $95 \mu \mathrm{m}$ in width. The pith is composed of thin-walled parenchyma cells with several irregularly distributed secretory cells (Fig. 1A). Intraxylary phloem differentiates concomitantly with external protophloem at the adaxial tips of vascular bundles (Fig. 1B). As secondary growth progresses further, additional intraxylary phloem differentiates from the adjacent cells (Fig. 1C).

At the end of the growing season the stems reach 4-6 $\mathrm{mm}$ in diameter and possess a single ring of vascular cambium in December. At this stage the plants possess fully mature leaves and then defoliate in subsequent months. During the dry season, radial growth remains suspended until April. When new leaves sprout at the end of May, the function of radial secondary growth is taken over by a newly initiated, complete ring of cambium. The first ring of successive cambium is initiated as small segments from pericyclic parenchyma cells situated outside the compacted protophloem (Fig. 1A). Repeated periclinal divisions in these cells form a 3-4-layer-wide band of radially arranged cambial cells (Fig. 1D). These segments become interconnected, to form a complete ring of the first successive cambium. The cambium is functionally bidirectional and produces secondary xylem centripetally and phloem centrifugally (Fig. 1F). The first element to be produced towards 

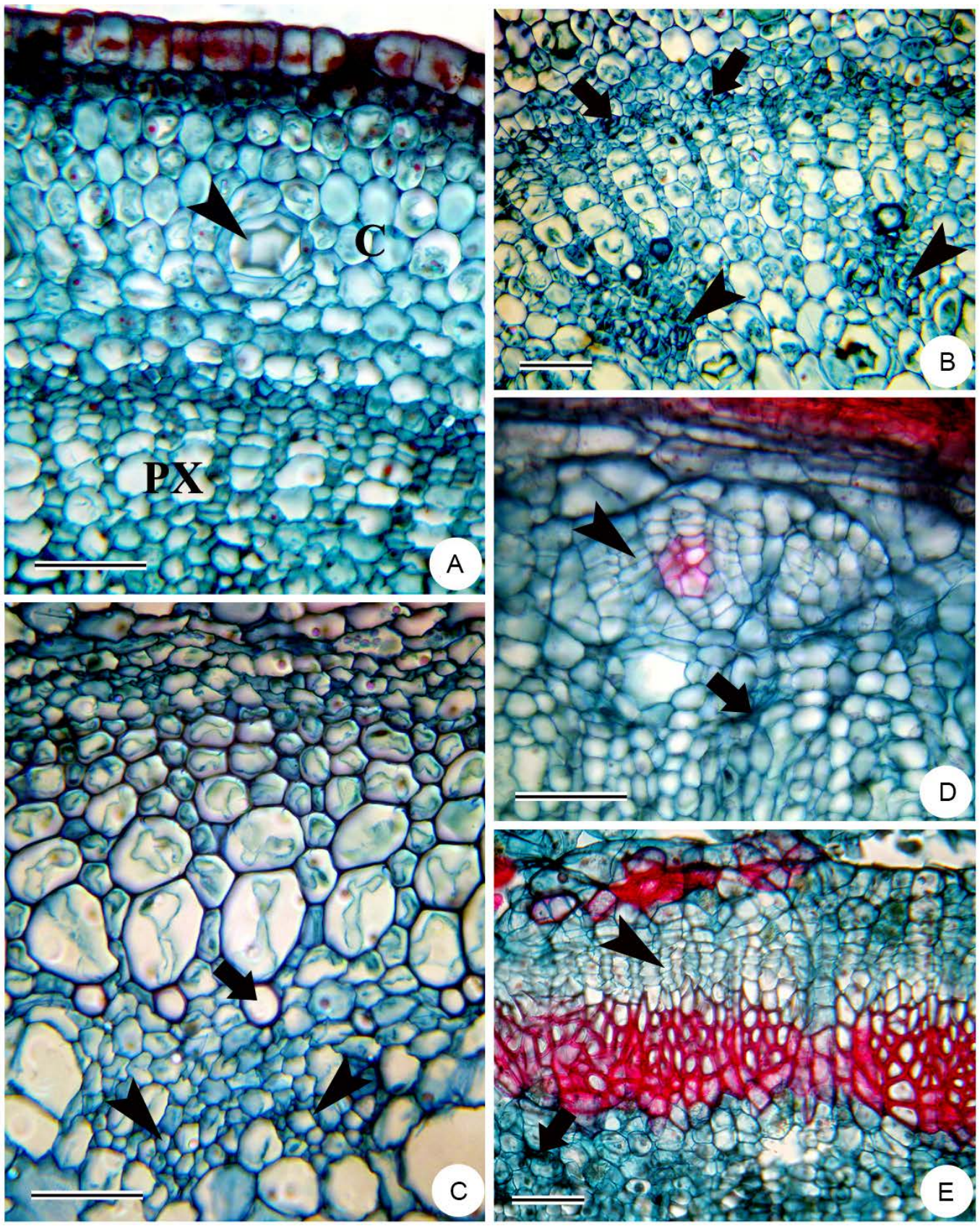

西
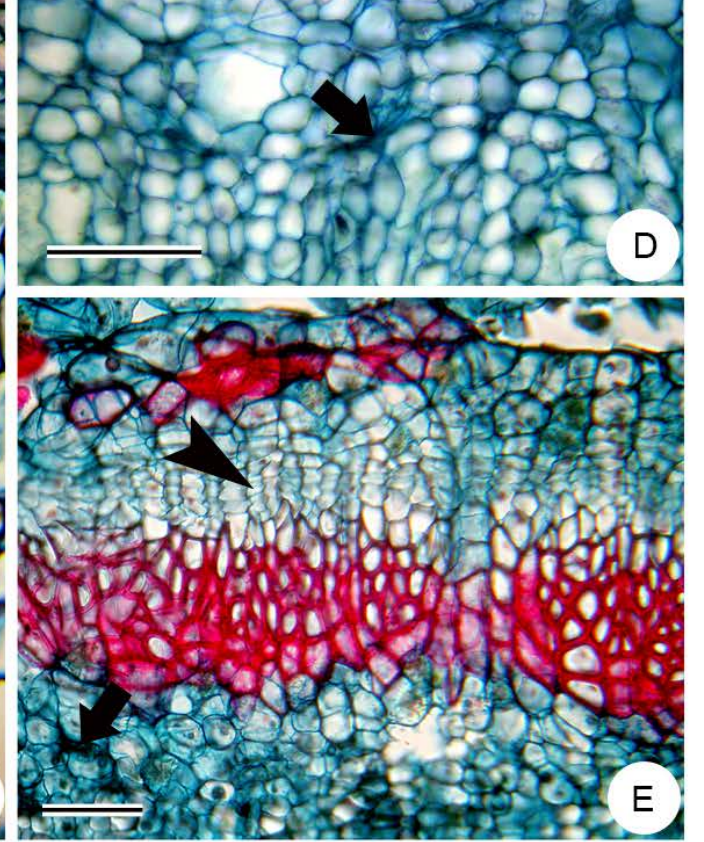

Fig. 1. Transverse view of young stem of Rivea hypocriteriformis Choisy. A - Young stem showing epidermis, one- to twolayered hypodermis, cortex (C) and differentiating primary xylem (PX). Arrowhead indicates a laticifer. B - Simultaneous differentiation of intraxylary phloem (arrowheads) and narrow external protophloem (arrows). C - Young stem at $7^{\text {th }}$ internode, showing well-differentiated intraxylary phloem (arrowheads). Arrow indicates protoxylem. D - Initiation of cambial segment (arrowhead) outside crushed protophloem (arrow). E - Newly formed cambium (arrowhead) showing a few recently formed xylem elements $(\mathrm{XY})$. Note the absence of wide vessels in a few early xylem derivatives. Arrow indicates crushed protophloem. Scale bar: A-E $=100 \mu \mathrm{m}$. 
the xylem side from each successive cambium consists of fibriform vessels and fibre tracheids (Fig. 2A, B). Wider vessel elements form only after the formation of some fibriform vessels and xylem fibre tracheids (Fig. 2B); occasionally, wide vessels differentiate first, followed by differentiation of fibriform vessels and fibre tracheids (Fig. 2C). Successive cambia formed thereafter fail to form a complete cylinder and become an anastomosing network of vasculature (Fig. 2D).

\section{STRUCTURE AND DEVELOPMENT}

OF INTRAXYLARY PHLOEM

Discrete strands of intraxylary phloem are observed on the internal margin of protoxylem (Fig. 2E). They develop at the $4^{\text {th }}$ visible internode from procambial derivatives, simultaneously with the development of external protophloem, when one or two protoxylem elements are differentiated (Fig. 1B). The intraxylary phloem derivatives increase in number and become prominently visible, with distinct sieve tubes and companion cells, only after the $7^{\text {th }}$ internode (Fig. 1C). As secondary growth progresses further, more intraxylary phloem elements are added from adjacent parenchymatous derivatives, which differ morphologically from the pith cells in having smaller diameter (Fig. 2F). Even in thick stems (20-25 $\mathrm{mm}$ in diameter), conducting sieve elements with open sieve pores are observed on the inner margin of the xylem derivatives, while nonconducting sieve elements show heavy accumulation of callose, while crushed sieve elements accumulate centripetally (Fig. 2E).

Intraxylary and external phloem consists of sieve tube elements, companion cells and axial parenchyma; phloem rays were observed only in external phloem. The dimensions of sieve tube elements do not vary significantly: the ranges were 236-281 (253 \pm 5.38$) \mu \mathrm{m}$ for length and 33-42 (37 \pm 2.11$) \mu \mathrm{m}$ for width.

\section{STRUCTURE OF SECONDARY XYLEM}

Mature stems are composed of several successive rings of secondary xylem alternating with phloem (Figs. 2D, 3A). Secondary xylem is diffuse-porous, with indistinct growth rings (Fig. 3B). The secondary xylem is composed of wide fibriform vessels (Fig. 3C), sparse vascicentric parenchyma, fibre tracheids and rays Fig. 3D, E). The rays are uni- to multiseriate, tall and heterocellular, with vertically upright cells intermixed with smaller and larger ray cells (Figs 3E, 4A). Interestingly, the multiseriate marginal ray cells become lignified and thick-walled, while the central cells are thin-walled and have distinct nuclei (Fig. 4A). The rays are $256-464(365 \pm 21.58) \mu \mathrm{m}$ high and $43-73$ $(53 \pm 8.42) \mu \mathrm{m}$ wide. The fibre tracheids are $807-$ $1087(968 \pm 28.74) \mu \mathrm{m}$ long and possess bordered pits (Fig. 3D). Bands of thin-walled parenchyma, a characteristic of many species of Convolvulaceae, are restricted to the first ring (Fig. 4B). The sparse vasicentric axial parenchyma are thickwalled and lignified, making them difficult to distinguish in cross section (Figs 3D, 4D). They run parallel around the vessels and form a sheath of radially flattened cells which is slightly thinner than the fibre walls (Fig. 4C, D).

The vessel elements are 164-267 (211 $\pm 14.61) \mu \mathrm{m}$ long and 153-173 (160 \pm 7.84$) \mu \mathrm{m}$ wide, with alternate bordered pits on their radial walls. In contrast, the fibriform vessels are exceptionally narrow, measuring 287-312 (299 \pm 6.77$)$ $\mu \mathrm{m}$ long and $32-47(38 \pm 1.79) \mu \mathrm{m}$ wide. Due to their narrowness it was difficult to distinguish them in cross section (Fig. 3B). The simple perforation plates are subterminal in position, with alternate bordered pits on their lateral walls. In thick stems, wider vessels often show the presence of tyloses due to protrusion of adjacent parenchyma into the vessel lumen (Fig. 4C-E). During the formation of tyloses, the nucleus and part of the cytoplasm migrate into the vessel lumen and appear as balloonshaped structures in the lumen. In some vessels the tyloses show thick lignified walls, while in others they differentiate into sclereids (Fig. 4C). They also show storage of starch grains as well as druses (Fig. 4D, E).

\section{DisCUSSION}

The Convolvulaceae are characterized by a climbing habit, but a few species are shrubs or arborescent (McDonald 1992; Rajput et al. 2013). 

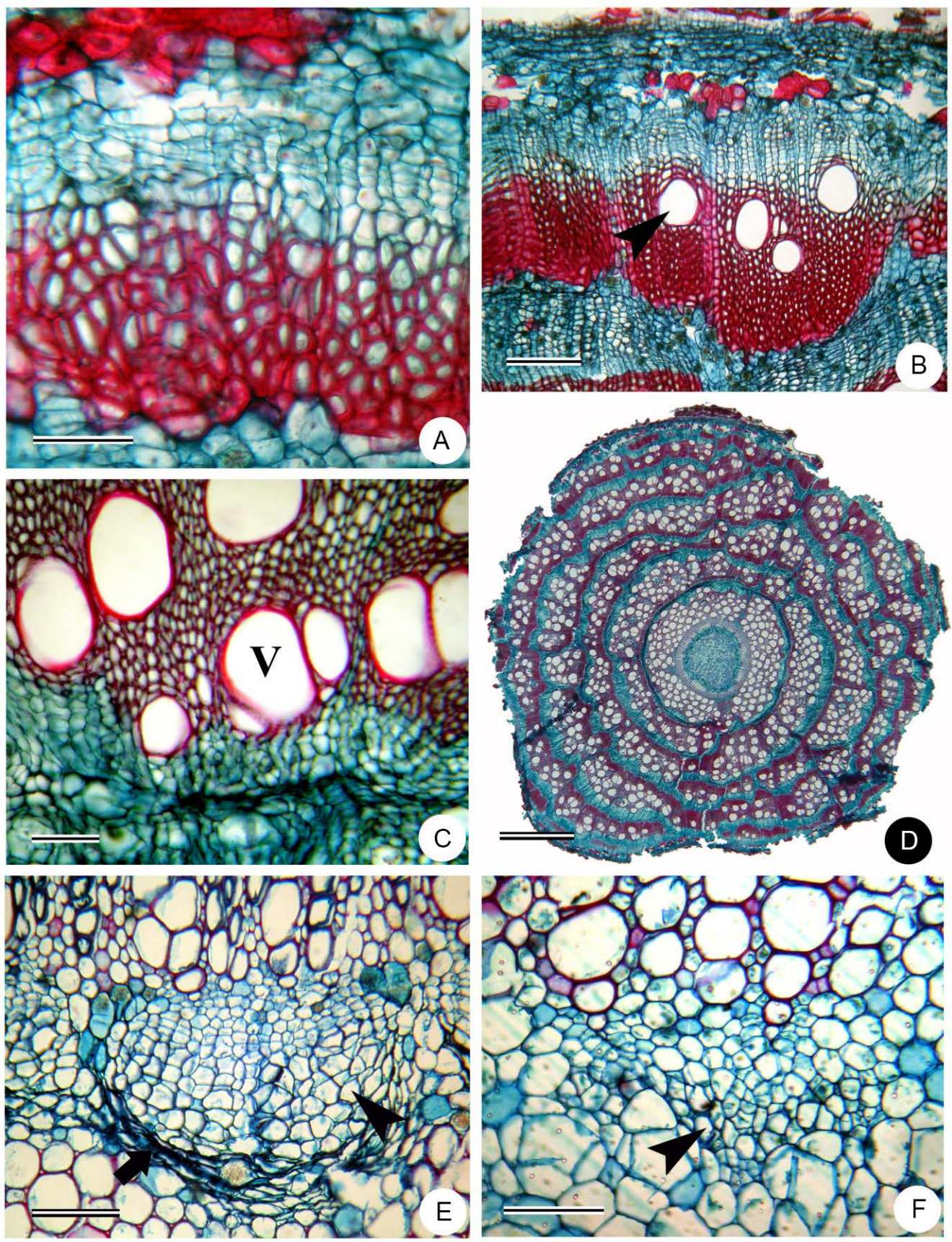

Fig. 2. Transverse view of young and mature stems of Rivea hypocriteriformis Choisy. A - Newly formed xylem, showing its products. Note the absence of wide vessels in the early stage of xylem differentiation. B - Formation of wider vessels after differentiation of a few xylem derivatives (arrowhead). C - Secondary xylem in one of the successive rings, showing vessels formed at the beginning of xylem differentiation $(\mathrm{V}=$ vessel $)$. $\mathrm{D}$ - Stem cross section, showing successive rings of cambia and their anastomosing network. E - Intraxylary phloem in thick stem (arrowhead). Note the non-conducting crushed phloem (arrow). F - Initiation of intraxylary phloem development (arrowhead). Scale bar: A $=200 \mu \mathrm{m} ; \mathrm{B} \& \mathrm{D}-\mathrm{F}=100 \mu \mathrm{m}$. 

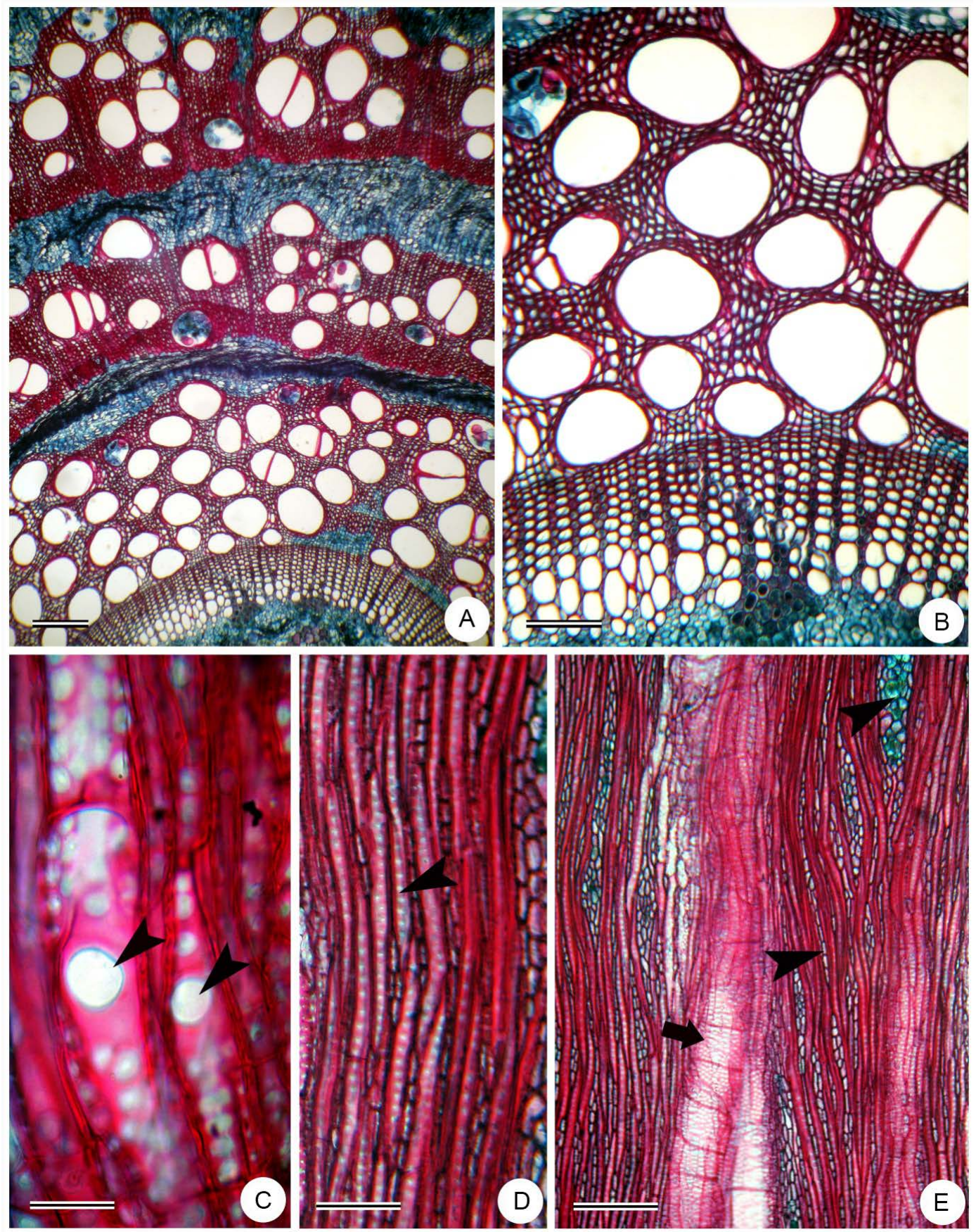

Fig. 3. Transverse (A \& B) and longitudinal (C-E) view of secondary xylem of Rivea hypocrateriformis Choisy. A - Successive rings of secondary xylem alternating with phloem rings. B - Structure of secondary xylem and arrangement of vessels and axial parenchyma cells. C - Fibriform vessel elements (arrowheads). Note the subterminal position of the perforation plate. D - Portion of secondary xylem, showing true tracheids (arrowhead). E - Structure of secondary xylem, showing wide vessels (arrow), tracheids and uni- to multiseriate rays (arrowhead). Scale bar: A $=750 \mu \mathrm{m} ; \mathrm{B} \& \mathrm{E}=250 \mu \mathrm{m} ; \mathrm{C}=50 \mu \mathrm{m} ; \mathrm{D}=100 \mu \mathrm{m}$. 

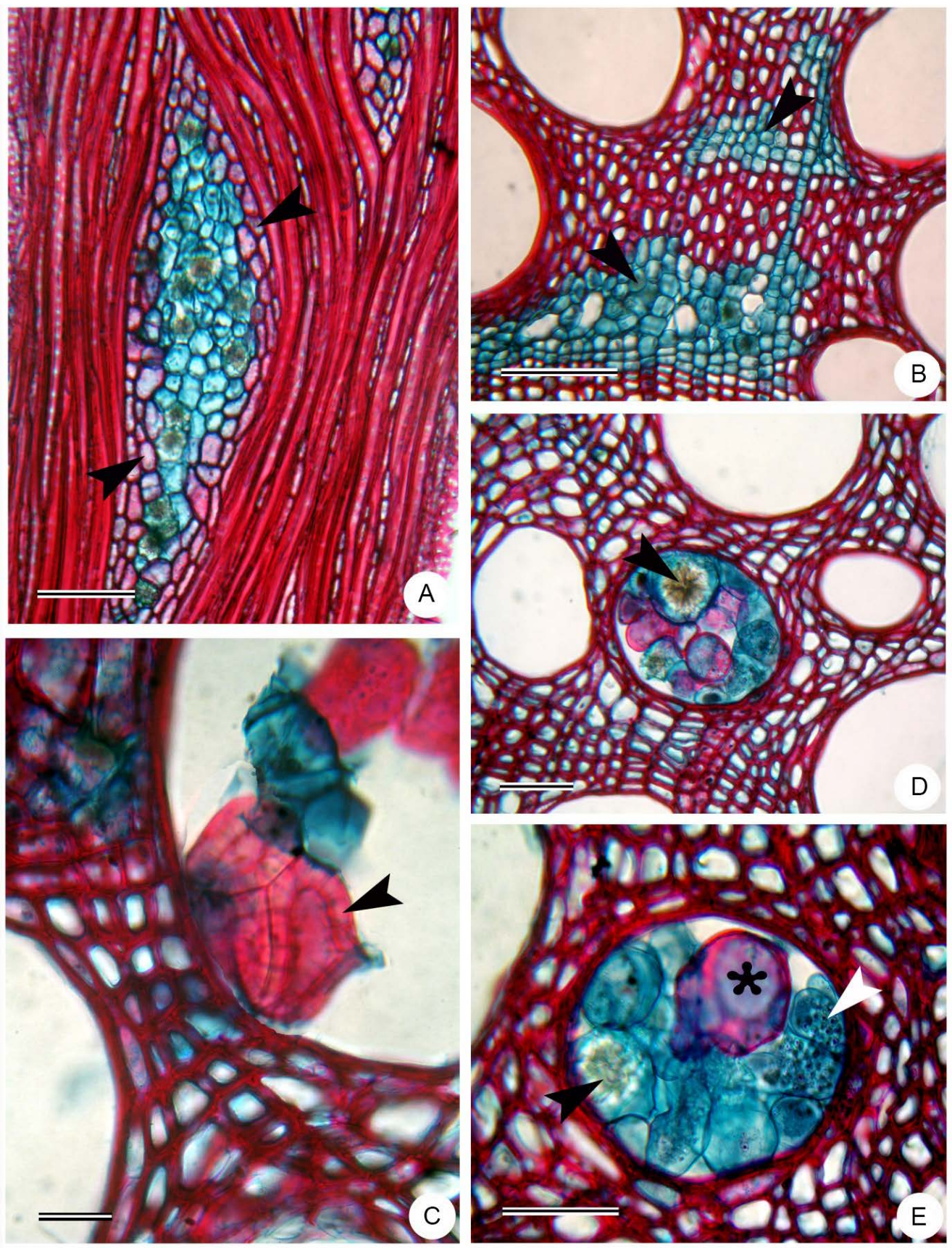

Fig. 4. Tangential longitudinal (A) and transverse (B-E) views of secondary xylem of Rivea hypocriteriformis Choisy. A - One of the wide rays in secondary xylem. Note the thick-walled marginal ray cells (arrowheads) and thin-walled central cell. B - Secondary xylem, showing islands of thin-walled parenchyma (arrowheads) embedded within lignified xylem derivatives. C - Vessel, showing differentiation of tyloses into sclereids (arrowhead). D - A vessel in secondary xylem, showing tyloses. Arrowhead indicates druses within tyloses. E - Enlarged view of vessel, showing deposition of druse (black arrowhead) and starch grains within tylose (white arrowhead). Note the thick-walled and lignified tylose (asterisk). Scale bar: A-E $=100 \mu \mathrm{m}$. 
In climbing plants, during the shift from a tree habit their mechanical architecture changed drastically in some taxa, resulting in the formation of successive cambia and inter- and intraxylary phloem (Hallier 1893; Carlquist \& Hanson 1991; McDonald 1992; Rajput et al. 2014). Since Hallier's (1893) first report on the occurrence of successive cambia in the Convolvulaceae, variation of the growth pattern has been reported a number of times (Pfeiffer 1926; Lowell \& Lucansky 1986; Carlquist \& Hanson 1991; McDonald 1992; Rajput et al. 2008, Patil et al. 2009; Terrazas et al. 2011; Rajput et al. 2013, 2014). The wood anatomy of Convolvulaceae has been described in the voluminous work Anatomy of Dicotyledons (Metcalfe \& Chalk 1950) and also by Carlquist and Hanson (1991).

In Rivea the function of radial secondary growth is taken over by additional rings of successive cambia as secondary growth progresses. These rings develop in a way similar to that described by previous workers (Hallier 1893; Lowell \& Lucansky 1986; Rajput et al. 2008, 2014; Terrazas et al. 2011). The present study of periodically collected samples indicates that a single ring of cambium develops each year and remains functional for one growing season for the production of secondary xylem and phloem derivatives. In the literature there is not much information on the frequency of successive cambia developing in one growing season. It has been noted that the development of successive cambia depends on the growth form of a given species; in annuals such as Atriplex L. and Chenopodium L., for example, a successive cambium is active for only a few weeks (Heklau et al. 2012). Month-old Spinacea plants showed simultaneous origination of 2-3 successive cambial rings (Rajput et al. 2010). In subshrubs and shrubs, cambium activity is prolonged, with a single cambium formed in one season (Rajput \& Rao 2003; Heklau et al. 2012). In this study I found that a single cambium remained functional for one growing season in young shoots, and in some samples of the main stem showed 2-3 functional rings which differentiated very little xylem in any of the rings, indicating that they had been initiated in the current growing season. Since the stems are narrow in climbing species, it is not possible to take multiple collections over time from the same plant in order to verify the initiation of number of successive cambial rings in one season. Further studies are needed to clarify the number of successive cambia formed in one year.

To adapt to the climbing habit, mechanical tissues need to be altered to provide stem flexibility and prevent breaking. Modification of vessel diameter helps to supply the required amount of water to a large crown. For these reasons the characteristic features of the climbing habit, described by earlier workers, are the occurrence of successive cambia, an abundance of parenchyma, wide and large rays (mostly thin-walled), and reduced mechanical tissue, with vessel dimorphism (Fisher \& Ewers 1991; Rowe \& Speck 1996; Carlquist 2001; Isnard \& Silk 2009; Rajput et al. 2013). These features are thought to provide stem flexibility for twisting around the supporting host without loss of conductivity of the secondary xylem. Such features are characteristic of stems of $R$. hypocriteriformis, which showed the presence of large and heterocellular rays, sparse vasicentric axial parenchyma, and vessel dimorphism. Islands of thin-walled parenchyma are present in Rivea but they are thicker than in other members of the Convolvulaceae (Carlquist \& Hanson 1991; Rajput et al. 2008, 2013). A unique feature I found in this study, not previously reported in the Convolvulaceae, is the occurrence of lignified marginal ray cells and thinner central ray cells.

The presence of thin-walled parenchymatous islands is characteristic of the Convolvulaceae, reported in most climbing species of the family (Lowell \& Lukansky 1986; Carlquist \& Hanson 1991; Terrazas et al. 2011; Rajput et al. 2008, 2013). With age, these parenchyma cells give rise to interxylary phloem in many members. I observed no such interxylary phloem formation even in stems $45 \mathrm{~mm}$ thick. The axial parenchyma cells distributed in the secondary xylem are sparsely vasicentric and lignified, making it difficult to distinguish them in cross section. They envelop the vessels; they may be protecting the wide vessels to 
some extent from the detrimental effects of air embolisms in flexible stems. Wide vessels are highly efficient for conducting water but are also susceptible to air embolisms (Carlquist 1991; Carlquist \& Hanson 1991). The presence of fibriform vessels in climbing species is correlated with resistance to air embolisms, and fibriform vessels are said to be as efficient as tracheids (Ellmore \& Ewers 1985; Carlquist 1991; Carlquist \& Hanson 1991; Rajput et al. 2008).

In many plants, tyloses form when vessels become inactive and lose their internal pressure (Evert 2006). Tyloses may undergo lignification and became thick-walled or may differentiate into sclereids (Evert 2006). Tyloses may store a variety of substances; I observed starch as well as druses in tyloses. The formation of tyloses in the vessel lumina is reported to be hormonally controlled, and they may be formed as a defense against pathogens (Vander Molen et al. 1987; Evert 2006).

The Convolvulaceae are also characterized by the formation of intraxylary phloem (Fukuda 1967; Carlquist \& Hanson, 1991; Rajput et al. 2008). In many species, cambial development occurs between the inner margin of xylem and intraxylary phloem (Carlquist \& Hanson 1991; Rajput et al. 2008; Carlquist 2013). In the material I studied, additional intraxylary phloem was added by adjacent parenchyma; no such cambial development has been reported in Rivea previously.

In Rivea, stem diameter increases through the formation of one successive ring of cambium in every growing season. The first cambium develops from pericyclic derivatives, and further cambia form from parenchyma cells located outside the phloem formed by the previous cambium. In Rivea hypocriteriformis, islands of thin-walled parenchyma cells were embedded in thick-walled xylem derivatives, but, unlike in other Convolvulaceae, they did not develop interxylary phloem even in thick stems. Intraxylary phloem formed on the adaxial side of the vascular bundles.

ACKNOWLEDGEMENTS. I thank Dr. Jan J. Wójcicki and both anonymous reviewers for their valuable suggestions. Funding for this work from the Science and Engineering Research Board (SERB), Government of India, is gratefully acknowledged.

\section{REFERENCES}

Berlyn G. P. \& Miksche J. P. 1976. Botanical Microtechnique and Cytochemistry. The Iowa State University Press, Ames, Iowa.

CARLquist S. 1991. Anatomy of vine and liana stem: a review and synthesis. In: F. E. Putz \& H. A. Mooney (eds), The Biology of Vines, pp. 53-72. Cambridge University Press, Cambridge.

Carlquist S. 2001. Comparative Wood Anatomy, Systematic Ecological and Evolutionary Aspects of Dicotyledonous Wood. Springer-Verlag, Heidelberg, New York.

CARLQUIST S. 2013 Interxylary phloem: diversity and functions. Brittonia 65(4): 477-495.

Carlquist S. \& Hanson M. A. 1991. Wood and stem anatomy of Convolvulaceae: a survey. Aliso 13: 51-94.

Ellmore G. S. \& Ewers F. W. 1985. Hydraulic conductivity in trunk xylem of elm, Ulmus americana. I.A.W.A. Journal 6: 303-307.

Evert R. F. 2006. Esau's Plant Anatomy ( $3^{\text {rd }}$ ed.). John Wiley and Sons, Hoboken, New Jersey.

Fisher J. B. \& Ewers F. W. 1991. Structural responses to stem injury in vines. In: F. E. Putz \& H. A. Mooney (eds), The Biology of Vines, pp. 99-124. Cambridge University Press, Cambridge.

FUKUDA S. 1967. Anatomical study of the internal phloem in the stems of dicotyledons with special reference to histogenesis. J. Fac. Sci. Univ. Tokyo, Sect. 3, Bot. 9: 313-375.

Hallier H. 1893. Versuch einer naturlichen Gliederung der Convolvulaceen auf morphologisher und anatomischer Grundlage. Bot. Jahrb. Syst. 16: 453-591.

Heklau H., Gasson P., Schweingruber F. \& BaAs P. 2012. Wood anatomy of Chenopodiaceae. I.A.W.A. Journal 33(2): 205-232.

ISNARD S. \& SILK W. K. 2009. Moving with climbing plants from Charles Darwin's time into the $21^{\text {st }}$ century. Amer. J. Bot. 96: 1205-1221.

Johansen D. A. 1940. Plant Microtechnique. Mc Graw Hill, New York.

Lowell C. \& LuCANSKy T. W. 1986. Vegetative anatomy and morphology of Ipomoea hederifolia (Convolvulaceae). Bull. Torrey Bot. Club 113: 382-397.

McDonald J. A. 1992. Evolutionary implications of typical and anomalous secondary growth in arborescent Ipomoea (Convolvulaceae). Bull. Torrey Bot. Club 119: 262-267.

Metcalfe C. R. \& Chalk L. 1950. Anatomy of the Dicotyledons. Clerendon Press, Oxford.

Obaton M. 1960. Les lianes ligneuses a structure anormale des forets dense d'afrique occidentale. Ann. Sci. Nat., Bot. 12(1): 1-220. 
Pant D. D. \& Bhatnagar S. 1975. Morphological studies in Argyreia Lour. (Convolvulaceae). Bot. J. Linn. Soc. 70: 45-69.

Patil V. S., Rao K. S. \& Rajput K. S. 2009. Development of intraxylary phloem and internal cambium in Ipomoea hederifolia (Convolvulaceae). J. Torrey Bot. Soc. 136: 423-432.

PfeIfFer H. 1926. Das abnorme Dickenwachstum. Handbuch der Pflanzenanatomie. 9. Borntraeger, Berlin.

Rajput K. S. \& Rao K. S. 2003. Cambial variant and xylem structure in the stem of Cocculus hirsutus (Menispermiaceae). I.A.W.A. Journal 24: 411-420.

Rajput K. S., Raole V. M. \& Gandhi D. 2008. Radial secondary growth, formation of successive cambia and their products in Ipomoea hederifolia L. (Convolvulaceae). Bot. J. Linn. Soc. 158: 30-40.

Rajput K. S., Patil V. S. \& Kapadane K. K. 2010. Development of lateral meristem and pattern of secondary growth in stems and roots of Spinacia oleraceae Linn. (Amaranthaceae). Feddes Repert. 121: 209-218.

Rajput K. S., Rao K. S. \& Patil V. S. 2013. Wood Anatomy and the development of interxylary phloem of Ipomoea hederifolia Linn. (Convolvulaceae). J. Pl. Growth Regulat. 32(3): 654-662.

Rajput K. S., Patil V. S. \& Rao K. S. 2014. Stem anatomy of dwarf subshrub Cressa cretica L. (Convolvulaceae). Flora 209(8): 408-413.

Rowe N. P. \& SPECK T. 1996. Biomechanical characteristics of the ontogeny and growth habit of the tropical liana Condylocarpon guianense (Apocynaceae). Int. J. Pl. Sci. 157: 406-417.

Terrazas T., Aguilar-Rodríguez S. \& Ojanguren C. T. 2011. Development of successive cambia, cambial activity, and their relationship to physiological traits in Ipomoea arborescens (Convolvulaceae) seedlings. Amer. J. Bot. 98: $765-774$.

Vander Molen G. E., Beckman C. H. \& Rodehorst E. 1987. The ultrastructure of tylose formation in resistant banana following inoculation with Fusarium oxysporum f. sp. cubense. Physiol. Molec. Pl. Pathol. 31: 185-200.

Wheeler E. A., BaAs P. \& Gasson P. E. (eds) 1989. IAWA list of microscopic features for hardwood identification. I.A.W.A. Bull. 10(3): 219-332.

Received 12 October 2015 